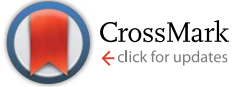

Cite this: RSC Adv., 2017, 7, 12201

Received 5th December 2016 Accepted 8th February 2017

DOI: $10.1039 / c 6 r a 27796 a$

rsc.li/rsc-advances

\title{
Exploring the catalytic activity of Lewis-acidic uranyl complexes in the nucleophilic acyl substitution of acid anhydrides $\uparrow$
}

\author{
Koichiro Takao* and Shin Akashi
}

\begin{abstract}
The catalytic activities of several uranyl complexes, such as $N, N^{\prime}$-disalicylidene-Ophenelyenediaminato(ethanol)dioxouranium(vI) $\left(\mathrm{UO}_{2}\right.$ (salophen) $\left.\mathrm{EtOH}\right)$, bis(dibenzoylmethanato)(ethanol) dioxouranium(VI) $\left(\mathrm{UO}_{2}(\mathrm{dbm})_{2} \mathrm{EtOH}\right)$, pentakis( $N, N$-dimethylformamide)dioxouranium(VI) $\left(\left[\mathrm{UO}_{2}(\mathrm{DMF})_{5}\right]^{2+}\right)$, and tetrakis(triphenylphosphine oxide)dioxouranium( $(\mathrm{VI})\left(\left[\mathrm{UO}_{2}\left(\mathrm{OPPh}_{3}\right)_{4}\right]^{2+}\right)$, were examined in the nucleophilic acyl substitution of acid anhydrides. Among them, $\left[\mathrm{UO}_{2}\left(\mathrm{OPPh}_{3}\right)_{4}\right]^{2+}$ was the most efficient to give ethyl acetate and acetic acid from acetic anhydride $\left(\mathrm{Ac}_{2} \mathrm{O}\right)$ and ethanol, and was resistant towards decomposition during the catalytic reaction. Several nucleophiles were also subjected to the catalytic acylation reaction using acetic and pivalic anhydride. Kinetic and spectroscopic studies suggested that $\left[\mathrm{UO}_{2}\left(\mathrm{OPPh}_{3}\right)_{4}\right]^{2+}$ interacts with $\mathrm{Ac}_{2} \mathrm{O}$ to form $\left[\mathrm{UO}_{2}\left(\mathrm{Ac}_{2} \mathrm{O}\right)(\mathrm{OPPh})_{3}\right]^{2+}$. Interaction of this actual catalyst with additional $\mathrm{Ac}_{2} \mathrm{O}$ determines the rate of the overall nucleophilic acyl substitution reaction.
\end{abstract}

\section{Introduction}

Although uranium is undoubtedly the most important element in nuclear engineering, the less abundant ${ }^{235} \mathrm{U}$ isotope is primarily employed in the practical utilization of atomic power. Accordingly, this fissile isotope has to be enriched in the nuclear fuel process, particularly in light water reactors. As a result, a huge amount of depleted uranium is generated and stored. ${ }^{\mathbf{1}}$

Recently, there have been numerous studies towards the use of uranium compounds as catalysts in organic syntheses to develop a sophisticated use for depleted uranium that has already been refined. ${ }^{2}$ In the former reports, three main methods appear to be present for organic syntheses: (i) catalysis using organouranium complexes, ${ }^{3-8}$ (ii) the activation of small molecules by low valent uranium complexes, ${ }^{8}$ and (iii) the activation of axial (namely, "-yl") oxygen atoms in the $[\mathrm{O}=\mathrm{U}=$ $\mathrm{O}]^{n+}$ moiety $(n=1,2) ;^{9-14}$ thus far, the first research direction has succeeded in the coupling reactions of alkynes and the polymerization of lactones, but the latter two do not attain actual catalytic systems and remain as stoichiometric reactions. Furthermore, these reaction systems always require dry

Laboratory for Advanced Nuclear Energy, Institute of Innovative Research, Tokyo Institute of Technology, 2-12-1 N1-32, O-okayama, Meguro-ku, 152-8550 Tokyo, Japan.E-mail:ktakao@lane.iir.titech.ac.jp

$\dagger$ Electronic supplementary information (ESI) available: Progress and efficiency of acylation using uranyl(vi) catalysts, ${ }^{1} \mathrm{H}$ NMR spectra supporting the decomposition of the catalysts and side reactions, plots of the initial rate under several conditions, and the molar absorption spectra of the uranyl(vi) species. See DOI: 10.1039/c6ra27796a anaerobic conditions because of the low stability of these (pre) catalysts towards oxygen and moisture.

Using the Lewis acidity of uranium should be another alternative for exploring its catalytic activity. Particularly, the uranyl ion $\left([\mathrm{O}=\mathrm{U}=\mathrm{O}]^{2+}, \mathrm{UO}_{2}{ }^{2+}\right)$ is highly Lewis acidic and exhibits strong hardness according to Pearson's HSAB principle. ${ }^{15}$ Therefore, any undesired side reactions arising from the organometallic behaviour of the uranium centre can be avoided, although some organouranyl compounds have been known to be formed in exceptional circumstances. ${ }^{16-19}$ As a matter of fact, several examples of uranyl-catalysed reactions including the alcoholysis of esters, ${ }^{20}$ Michael additions, ${ }^{21-26}$ Diels-Alder reactions ${ }^{27}$ and polymerizations ${ }^{28-30}$ have been reported to date. Furthermore, its robust axial structure only allows a planar ligand arrangement in the equatorial coordination plane. Such a ligand set may provide some regio- or chemoselectivity to the reaction of interest.

Although the Lewis basicity of "-yl" oxygen atoms is not very high, they can interact with a strong Lewis acid such as $\mathrm{B}\left(\mathrm{C}_{6} \mathrm{~F}_{5}\right)_{3} \cdot{ }^{31,32}$ Previously, Chen and co-workers studied the catalytic activity of the oxo ions of V(Iv), Mo(vI), W(vI) and $\mathrm{Cr}(\mathrm{vI})$ in the nucleophilic acyl substitution of acid anhydrides. ${ }^{33,34}$ Among them, a high efficiency was recorded when using $\mathrm{VO}(\mathrm{OTf})_{2}$ and $\mathrm{MoO}_{2} \mathrm{Cl}_{2}$. In their catalytic systems, these oxo ions are believed to be amphoteric and can efficiently activate acid anhydrides. This information strongly motivated us to examine the catalytic activity of the uranyl ion, although the Lewis basicity of its "-yl" oxygen atoms is rather weak.

In this study, several uranyl complexes were tested as Lewis acid catalysts in the nucleophilic acyl substitution to clarify 
their requirements as a catalyst. Several nucleophiles were also subjected to the catalytic acylation reaction using acetic and pivalic anhydride. Furthermore, kinetic and spectroscopic studies were also performed to understand the catalytic mechanism in detail.

\section{Results and discussion}

\section{Catalyst screening}

At least one of the equatorial coordination sites of a uranyl complex must be offered for a substrate to be activated. Therefore, one or more leaving ligand(s) should be present in the uranyl catalyst. In this study, $N, N^{\prime}$-disalicylidene-o-phenelyenediaminato(ethanol)dioxouranium(vI) $\quad\left(\mathrm{UO}_{2}\right.$ (salophen) EtOH, 1), bis(dibenzoylmethanato)(ethanol)dioxouranium(vI) $\left(\mathrm{UO}_{2}(\mathrm{dbm})_{2} \mathrm{EtOH}, 2\right)$, pentakis( $N, N$-dimethyl-formamide)dioxouranium(vi) $\left(\left[\mathrm{UO}_{2}(\mathrm{DMF})_{5}\right]^{2+}, 3\right)$, and tetrakis(triphenylphosphine oxide)dioxouranium(vi) $\left(\left[\mathrm{UO}_{2}\left(\mathrm{OPPh}_{3}\right)_{4}\right]^{2+}, 4\right)$ were employed as the catalyst candidates. Fig. 1 shows the schematic structures of these uranyl complexes. Acetic anhydride $\left(\mathrm{Ac}_{2} \mathrm{O}\right)$ and ethanol (EtOH) were selected as substrates to test these complexes in the acyl substitution reaction (eqn (1)).\$ The results obtained from the catalyst screening are summarized in Table 1.

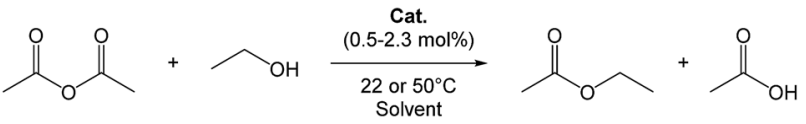

First, complexes 1 and 2 were examined in $\mathrm{CDCl}_{3}$. Previously, our group reported that $\mathbf{1}$ and its related complexes tend to release a monodentate ligand, such as $\mathrm{EtOH}$, to form a dimeric complex, $\left[\mathrm{UO}_{2}(\text { salophen })\right]_{2}$, in chlorinated, noncoordinating solvents such as $\mathrm{CHCl}_{3}$ and $\mathrm{CH}_{2} \mathrm{Cl}_{2} \cdot{ }^{35}$ Therefore, we expected that a substrate will be efficiently activated through this substitution reaction with the initially coordinated EtOH molecule. Nevertheless, no progress of eqn (1) was observed at $22{ }^{\circ} \mathrm{C}$ in both systems. When the sample solutions were warmed to $50{ }^{\circ} \mathrm{C}$, the desired reactions started, as shown in Fig. S1 (ESI $\dagger$ ). To reach an yield $>90 \%$, it took $7 \mathrm{~h}$ and $4 \mathrm{~h}$ at $50{ }^{\circ} \mathrm{C}$ when using 1 and 2 , respectively. The obtained products were EtOAc and $\mathrm{AcOH}$ only, demonstrating the high selectivity of these systems. On the other hand, the ${ }^{1} \mathrm{H}$ NMR spectra revealed that both complexes underwent partial or full decomposition. This would be due to $\mathrm{AcOH}$ that was generated, as shown in eqn (1). Complex 1 appeared to be more resistant towards the decomposition with acetic acid because of its more stable tetradentate chelate, although new signals arising from several salophen ${ }^{2-}$ species including a free $N, N^{\prime}-$ disalicylidene-o-phenylenediamine $\left(\mathrm{H}_{2} \mathrm{salophen}\right)$ were also detected, as seen in Fig. S2 (ESI $\dagger$ ). In contrast, 2 was completely decomposed within $2 \mathrm{~h}$ as free dibenzoylmethane ( $\mathrm{Hdbm}$ ) was observed, as seen in Fig. S3 (ESI $\dagger$ ). Through these experiments, it has been evidenced that the Lewis acidity of these uranyl

\$ Control experiments in the absence of a uranyl complex did not result in any significant progress of the acylation reaction (e.g., $0.8 \%$ yield after $2 \mathrm{~h}$ in a $\mathrm{CH}_{2} \mathrm{Cl}_{2}$ solution of $\left.0.5 \mathrm{M} \mathrm{Ph}\left(\mathrm{CH}_{2}\right)_{2} \mathrm{OH}+0.5 \mathrm{M} \mathrm{Ac}_{2} \mathrm{O}\right)$.

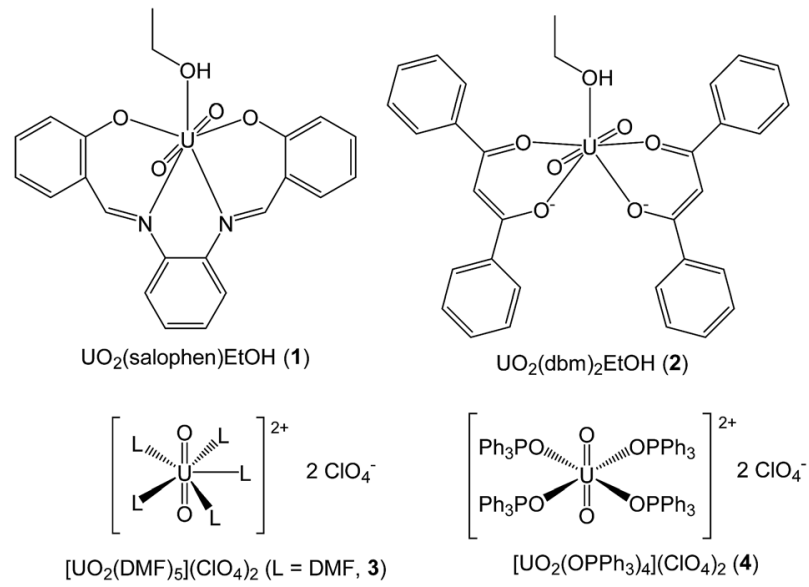

Fig. 1 A schematic structure of the uranyl( $(\mathrm{vl})$ complexes tested in this study $(\mathrm{EtOH}=$ ethanol).

complexes actually catalyses the acyl substitution reaction of $\mathrm{Ac}_{2} \mathrm{O}$. However, it is better to shift to other uranyl complexes because the mechanism and kinetics cannot be discussed in detail.

As another alternative for the catalyst in the acyl substitution reaction, complex 3 was investigated. Although the equatorial plane of the uranyl ion of this complex is fully occupied with 5fold coordination offered by the DMF molecules, the exchange or substitution reaction of these monodentate ligands is expected to occur in high frequency because of the labile character of the uranyl ion. ${ }^{35-37}$ Therefore, one or both of the substrates in eqn (1) may enter the uranyl coordination sphere. The reaction progress at $22{ }^{\circ} \mathrm{C}$ in the presence of $3(2.3 \mathrm{~mol} \%)$ in $\mathrm{CD}_{3} \mathrm{CN}$ is displayed in Fig. S4 (ESI $\dagger$ ). On one hand, the substrates shown in eqn (1) are actually converted to the desired products in $87 \%$ yield after $6 \mathrm{~h}$. On the other hand, the ${ }^{1} \mathrm{H}$ NMR spectrum in Fig. S5 (ESI $\dagger$ ) indicates the occurrence of unknown products at $8.27 \mathrm{ppm}$ ( $c f$. CHO- of DMF at $8.60 \mathrm{ppm}$ ). These substances cannot be a result of the reaction between $\mathrm{Ac}_{2} \mathrm{O}$ and DMF. The peak integrals indicate that the concentrations of these undesired products are rather small when compared with that of the desired ester, whereas the uranyl complex ( $2.3 \mathrm{~mol} \%$ in total) suffered from this undesired reaction. This means that several mixed ligand complexes other than 3 were also present in the reaction mixture. These in situ generated uranyl complexes may also exhibit some catalytic activity in the reaction shown in eqn

Table 1 A summary of the catalyst screening in the nucleophilic acyl substitution of acetic anhydride using ethanol ${ }^{a}$

\begin{tabular}{lllll}
$\begin{array}{l}\text { Catalyst } \\
(\mathrm{mol} \%)\end{array}$ & Solvent & $T /{ }^{\circ} \mathrm{C}$ & Time/h & Yield/\% \\
\hline $\mathbf{1}(0.5)$ & $\mathrm{CDCl}_{3}$ & 50 & 7 & 90 \\
$\mathbf{2}(0.5)$ & $\mathrm{CDCl}_{3}$ & 50 & 4 & 90 \\
$\mathbf{3}(2.3)$ & $\mathrm{CD}_{3} \mathrm{CN}$ & 22 & 6 & 87 \\
$\mathbf{4}(1.3)$ & $\mathrm{CD}_{2} \mathrm{Cl}_{2}$ & 22 & 2 & 97
\end{tabular}

${ }^{a}$ Reaction conditions: $0.50 \mathrm{M} \mathrm{Ac}_{2} \mathrm{O}, 0.50 \mathrm{M}$ EtOH and the uranyl complex were loaded in $\mathrm{CD}_{2} \mathrm{Cl}_{2}$. 
(1). The occurrence of unknown catalysts makes further discussion on the kinetics and mechanism complicated. Therefore, it is necessary to find a monodentate ligand with high stability towards acid anhydrides. Nevertheless, it should be emphasized that the higher catalytic activity of a uranyl complex was successfully attained in use of the solvate complex 3 as demonstrated by the lower reaction temperature.

Triphenylphosphine oxide $\left(\mathrm{OPPh}_{3}\right)$ is one of strong monodentate ligands for uranyl and could be durable enough to remain unchanged under the reaction conditions shown in eqn (1) because of its small potential to react with acid anhydrides and carboxylic acid. An isolable form of the uranyl-OPPh complex is $\left[\mathrm{UO}_{2}\left(\mathrm{OPPh}_{3}\right)_{4}\right]^{2+}(4)$, which is usually obtained as a salt of a poorly coordinating anion such as $\mathrm{ClO}_{4}{ }^{-}$and $\mathrm{TfO}^{-} .^{38-40}$ The catalytic activity of $\mathbf{4}$ was examined in a similar manner to the abovementioned test systems. Fig. 2 shows the reaction progress in the presence of $4(1.3 \mathrm{~mol} \%)$ in $\mathrm{CD}_{2} \mathrm{Cl}_{2}$ at $22^{\circ} \mathrm{C}$. As a consequence, the products in eqn (1) were formed in $97 \%$ yield within $2 \mathrm{~h}$. It is noteworthy that $\mathrm{OPPh}_{3}$ remains unchanged in this system. In summary, the catalyst screening in Table 1 concluded that 4 is, in hand, the best uranyl complex to catalyse the reaction shown in eqn (1) from the viewpoints of activity and durability. Usually, the most popular coordination number of uranyl complexes in its equatorial plane is 5 , as revealed by 1,2 , and 3 (Fig. 1). Even in the complexation of uranyl with $\mathrm{OPPh}_{3}$, the pentacoordinate complex, $\left[\mathrm{UO}_{2}\left(\mathrm{OPPh}_{3}\right)_{5}\right]^{2+}(5)$, tends to be formed below $-40{ }^{\circ} \mathrm{C}$ (vide infra), where the thermal vibrations of the bulky $\mathrm{OPPh}_{3}$ ligands decrease. When the solution is warmed, complex 5 tends to release $\mathrm{OPPh}_{3}$ to give the 4 -fold complex 4 because of the steric hindrance between the neighboring $\mathrm{OPPh}_{3}$ molecules in the coordination sphere. As a result, some Lewis-acidic vacancies would be still left in the uranyl

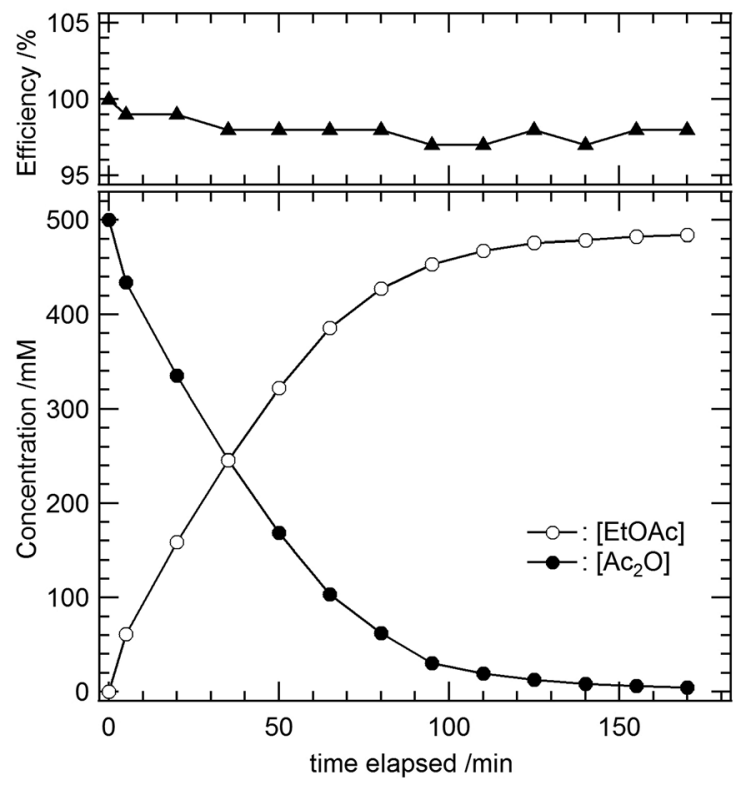

Fig. 2 The progress and efficiency of the acetylation of ethanol catalysed by $\left[\mathrm{UO}_{2}\left(\mathrm{OPPh}_{3}\right)_{4}\right]^{2+}(4,6.5 \mathrm{mM}, 1.3 \mathrm{~mol} \%)$ in $\mathrm{CD}_{2} \mathrm{Cl}_{2}$ at $22{ }^{\circ} \mathrm{C}$. Initial conditions: $\left[\mathrm{Ac}_{2} \mathrm{O}\right]=0.50 \mathrm{M}$ and $[\mathrm{EtOH}]=0.50 \mathrm{M}$. equatorial plane of $\mathbf{4}$, which can be offered to the activation of a substrate in the current catalytic system.

\section{Acyl substitution reactions catalyzed by complex 4}

With the optimal catalyst $\mathbf{4}$, the catalytic acetylation and pivalation of several nucleophiles, including alcohols and thiophenol, were examined. The results are summarized in Table 2 . In most cases except for ternary alcohols, the desired acylation products were obtained in good yield together with the carboxylic acids corresponding to the anhydride used. As a general trend, the acetylation was much faster than the corresponding pivalation, implying that the steric hindrance of an anhydride affects the reaction rate. When compared to entry 1 , a much shorter reaction time was required for both the acetylation and pivalation of 2-phenylethyl alcohol $\left(\mathrm{Ph}\left(\mathrm{CH}_{2}\right)_{2} \mathrm{OH}\right.$, entry 2). This suggests that coordination of less stericallyhindered nucleophiles, such as $\mathrm{EtOH}$, inhibits the catalytic activity of the uranyl ion. As a matter of fact, the reaction rate decreased, when extra EtOH was added to the reaction (Fig. S6, ESI $\dagger$ ). Such inhibition could also be the case in entry 3, where the carbonyl and hydroxyl groups of hydroxyacetone may interact with or chelate to the uranyl ion to prevent the desired acylation reaction. Nevertheless, this nucleophile is still amenable to acylation in quantitative yield, although a longer reaction time than $\mathrm{Ph}\left(\mathrm{CH}_{2}\right)_{2} \mathrm{OH}$ is required.

Entry 4 shows that tert-butyl alcohol is actually reactive in the current system even without any additional treatments such as raising the temperature and the addition of ternary amines. This point is distinguishable from the acylations catalyzed by vanadyl and molybdenyl ions, where this tertiary alcohol was completely inert towards the acylation reaction. ${ }^{33,34}$ The yield of tert-butyl acetate in entry 4 was $68 \%$ after $4 \mathrm{~h}$, while $\mathrm{Ac}_{2} \mathrm{O}$ already disappeared in the sample solution. This result was reproducible. Except for the expected products and leftover tertbutyl alcohol, the ${ }^{1} \mathrm{H}$ NMR spectrum of this sample (Fig. S7, $\left.\mathrm{ESI}^{\dagger}\right)$ revealed the presence of isobutene $\left[\delta / \mathrm{ppm}: 1.73\left(\mathrm{t}, J_{\mathrm{HH}}=\right.\right.$

Table $2 \quad\left[\mathrm{UO}_{2}\left(\mathrm{OPPh}_{3}\right)_{4}\right]^{2+}$-catalyzed acetylation $\left(\mathrm{R}^{\prime}=\mathrm{CH}_{3}\right)$ and pivalation $\left(\mathrm{R}^{\prime}=\mathrm{C}\left(\mathrm{CH}_{3}\right)_{3}\right)$ of various nucleophiles ${ }^{a}$

\begin{tabular}{llll}
\hline & & \\
\hline
\end{tabular}


$\left.1.2 \mathrm{~Hz}, 6 \mathrm{H}, \mathrm{H}_{2} \mathrm{C}=\mathrm{C}\left(\mathrm{CH}_{3}\right)_{2}\right), 4.66$ (septet, $J_{\mathrm{HH}}=1.2 \mathrm{~Hz}, 2 \mathrm{H}$, $\left.\mathrm{H}_{2} \mathrm{C}=\mathrm{C}\left(\mathrm{CH}_{3}\right)_{2}\right)$ ], which is the product resulting from the $\mathrm{E}_{1}$ reaction of tert-butyl alcohol. Another product in this side reaction was water, which also consumes the anhydride to give the corresponding carboxylic acid. Trityl alcohol was also tested as another sterically hindered nucleophile (entry 5). As a result, the progress of the acetylation of this bulky nucleophile was actually observed, although the reaction was so sluggish that it took 3 days to reach $63 \%$ yield. This is also much different from the inertness of vanadyl and molybdenyl catalysts in the acylation of trityl alcohol. ${ }^{33,34}$ Such a difference may be related to the size of the metal center because the ionic radius of $U^{6+}(0.73 \AA$ at 6-coordinated) is much greater than those of $\mathrm{V}^{4+}(0.53 \AA$ at 5-coordinated) and $\mathrm{Mo}^{6+}(0.59 \AA$ at 6-coordinated $){ }^{41}$

Phenol and thiophenol (entries 6 and 7) provide a good contrast of the difference in nucleophilic moieties. The nucleophilicity of $\mathrm{PhS}^{-}$is widely known to be much greater than that of $\mathrm{PhO}^{-}$. Nevertheless, phenol as a nucleophile exhibited a higher efficiency than thiophenol in terms of the reaction rate and yield. This difference appears to be related to the hardness of the nucleophilic atoms, although the details are still unclear.

\section{Reaction kinetics and catalysis mechanism}

Mechanistic insights into the nucleophilic acyl substitution reaction catalyzed by 4 were obtained by investigating how the concentrations of the substrates affected the reaction rate. Herein, the acetylation of $\mathrm{Ph}\left(\mathrm{CH}_{2}\right)_{2} \mathrm{OH}$ (entry 2, Table 2) was employed as a model reaction. Fig. 3 a shows the progress of this reaction in $\mathrm{CD}_{2} \mathrm{Cl}_{2}$ at $22{ }^{\circ} \mathrm{C}$ under different initial concentrations of $\mathrm{Ac}_{2} \mathrm{O}\left(\left[\mathrm{Ac}_{2} \mathrm{O}\right]_{\text {ini }}\right)$. Upon increasing $\left[\mathrm{Ac}_{2} \mathrm{O}\right]_{\text {ini }}$, the reaction rate clearly increased. The initial rate $\left(v_{\text {ini }}\right)$ estimated from Fig. 3a was plotted against $\left[\mathrm{Ac}_{2} \mathrm{O}\right]_{\text {ini }}$ as shown in Fig. S8 (ESI $\dagger$ ). As a result, $v_{\text {ini }}$ versus $\left[\mathrm{Ac}_{2} \mathrm{O}\right]_{\text {ini }}{ }^{2}$ shows a linear relationship with a slope equal to $1.04 \times 10^{-3} \mathrm{M}^{-1} \mathrm{~s}^{-1}$. We also examined the dependency of $v_{\text {ini }}$ on the initial concentration of the nucleophile $\left(\left[\mathrm{Ph}\left(\mathrm{CH}_{2}\right)_{2} \mathrm{OH}\right]_{\text {ini }}\right)$. However, the progress of the reaction was almost the same regardless of the different concentrations of $\left[\mathrm{Ph}\left(\mathrm{CH}_{2}\right)_{2} \mathrm{OH}\right]_{\text {ini }}$, as shown in Fig. S9 $\left(\mathrm{ESI}^{\dagger}\right)$ at least under the tested conditions $\left(\left[\mathrm{Ph}\left(\mathrm{CH}_{2}\right)_{2} \mathrm{OH}\right]_{\text {ini }}=0.25-1.00 \mathrm{M}\right)$. This means that $\mathrm{Ph}\left(\mathrm{CH}_{2}\right)_{2} \mathrm{OH}$ does not participate in the rate-determining step of this catalytic acyl substitution reaction.

When $\mathrm{Ac}_{2} \mathrm{O}$ interacts with 4, its $\mathrm{OPPh}_{3}$ ligand(s) may dissociate from $\mathrm{UO}_{2}{ }^{2+}$. Therefore, we also studied the dependency of $v_{\text {ini }}$ on the concentration of free $\mathrm{OPPh}_{3}\left(\left[\mathrm{OPPh}_{3}\right]_{\text {free }}\right)$. The results are displayed in Fig. $3 \mathrm{~b}$. With increasing $\left[\mathrm{OPPh}_{3}\right]_{\text {free, }}$ the reaction rate decreases. In Fig. S10 (ESI $\dagger$ ), $v_{\text {ini }}$ is proportional to $\left[\mathrm{OPPh}_{3}\right]_{\text {free }}{ }^{-1}$ with a slope equal to $6.54 \times 10^{-7} \mathrm{M}^{2} \mathrm{~s}^{-1}$.

In conclusion, the following is the rate equation for the acetylation of $\mathrm{Ph}\left(\mathrm{CH}_{2}\right)_{2} \mathrm{OH}$ catalyzed by 4 .

$$
v_{\text {ini }}=k\left[\mathrm{Ac}_{2} \mathrm{O}\right]^{2}\left[\mathrm{OPPh}_{3}\right]^{-1}[4]
$$

The rate constant ( $k$ ) of eqn (2) was estimated to be $4.02 \times$ $10^{-4} \mathrm{M}^{-1} \mathrm{~s}^{-1}$ at $22{ }^{\circ} \mathrm{C}$.

Further mechanistic information should be included in eqn (2) because multi-body collision is unlikely to occur. Thus, there should be an equilibrium preceding the rate-determining
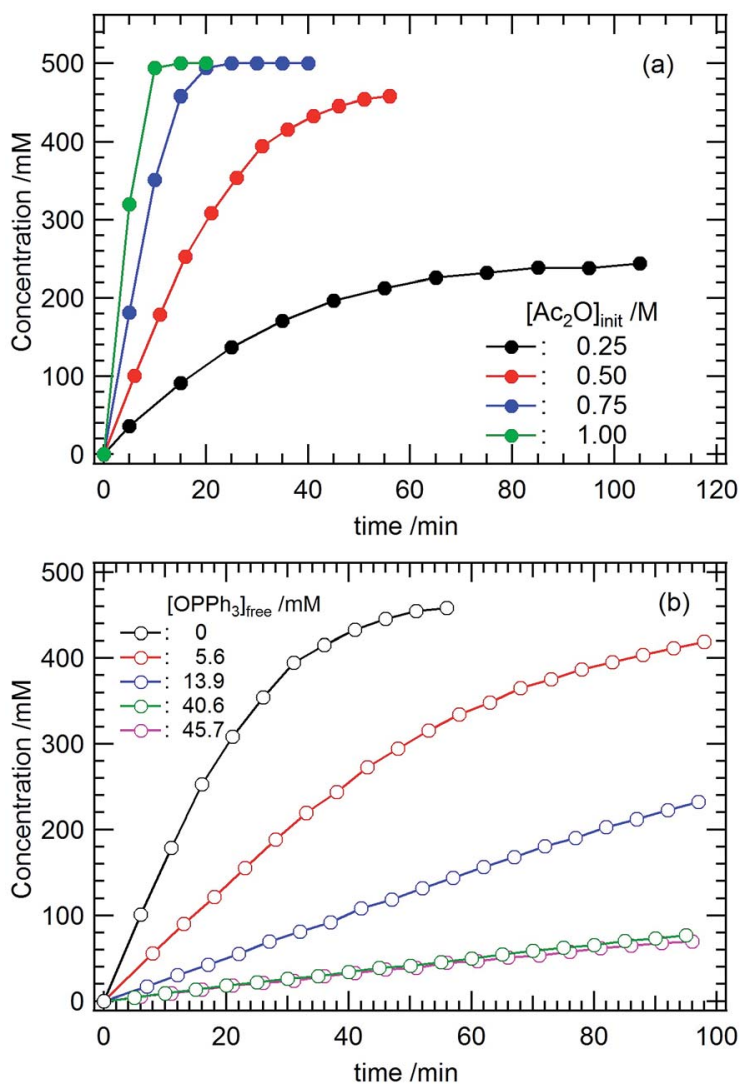

Fig. 3 The progress of the acetylation of $\mathrm{Ph}\left(\mathrm{CH}_{2}\right)_{2} \mathrm{OH}$ catalysed by $\left[\mathrm{UO}_{2}\left(\mathrm{OPPh}_{3}\right)_{4}\right]^{2+}$ (4) in $\mathrm{CD}_{2} \mathrm{Cl}_{2}$ at $22^{\circ} \mathrm{C}$. (a) $\left[\mathrm{Ac}_{2} \mathrm{O}\right]$ dependency; initial condition: $0.50 \mathrm{M} \mathrm{Ph}\left(\mathrm{CH}_{2}\right)_{2} \mathrm{OH}, 0.25-1.00 \mathrm{M} \mathrm{Ac}_{2} \mathrm{O}$ and $6.5 \mathrm{mM} \mathrm{4}$, and (b) [OPPh$h_{3}$ ] dependency; initial condition: $0.50 \mathrm{M} \mathrm{Ph}\left(\mathrm{CH}_{2}\right)_{2} \mathrm{OH}, 0.50 \mathrm{M}$ $\mathrm{Ac}_{2} \mathrm{O}, 6.5 \mathrm{mM} 4$ and $0-45.7 \mathrm{mM} \mathrm{OPPh}_{3}$.

step. When $\mathrm{Ac}_{2} \mathrm{O}$ was added to the $\mathrm{CD}_{2} \mathrm{Cl}_{2}$ solution containing 4, the yellow color arising from the uranyl compound immediately diminished, implying ligand substitution between the coordinated $\mathrm{OPPh}_{3}$ and $\mathrm{Ac}_{2} \mathrm{O}$. In contrast, any interaction of $\mathrm{Ph}\left(\mathrm{CH}_{2}\right)_{2} \mathrm{OH}$ with 4 was unlikely to occur despite its nucleophilicity because $v_{\text {ini }}$ is independent of $\left[\mathrm{Ph}\left(\mathrm{CH}_{2}\right)_{2} \mathrm{OH}\right]_{\text {ini }}$, as shown in Fig. S9 (ESI $\dagger$ ). This could be ascribed to steric hindrance arising from the phenyl groups. The complexation reaction between 4 and $\mathrm{Ac}_{2} \mathrm{O}$ was studied in detail using a UVvis absorption spectrophotometric titration study. The obtained spectral series recorded at different $\left[\mathrm{Ac}_{2} \mathrm{O}\right]$ is shown in Fig. 4. Upon increasing $\left[\mathrm{Ac}_{2} \mathrm{O}\right]$, a decrease in the intensity of the finely structured absorption bands arising from ligand-to-metal charge transfer (LMCT) in the $\mathrm{UO}_{2}{ }^{2+}$ moiety was observed together with a slight red shift in the peak maxima. This observation indicates that $\mathrm{OPPh}_{3}$ in $\mathbf{4}$ was substituted by $\mathrm{Ac}_{2} \mathrm{O}$ as shown in eqn (3).

$$
\begin{aligned}
{\left[\mathrm{UO}_{2}\left(\mathrm{OPPh}_{3}\right)_{4}\right]^{2+} } & (\mathbf{4})+\mathrm{Ac}_{2} \mathrm{O}= \\
& {\left[\mathrm{UO}_{2}\left(\mathrm{Ac}_{2} \mathrm{O}\right)\left(\mathrm{OPPh}_{3}\right)_{4-n}\right]^{2+}+n \mathrm{OPPh}_{3} }
\end{aligned}
$$

Although no isosbestic points were observed in Fig. 4, principal component analysis (PCA $)^{\mathbf{4 2 , 4 3}}$ has suggested that a total of 


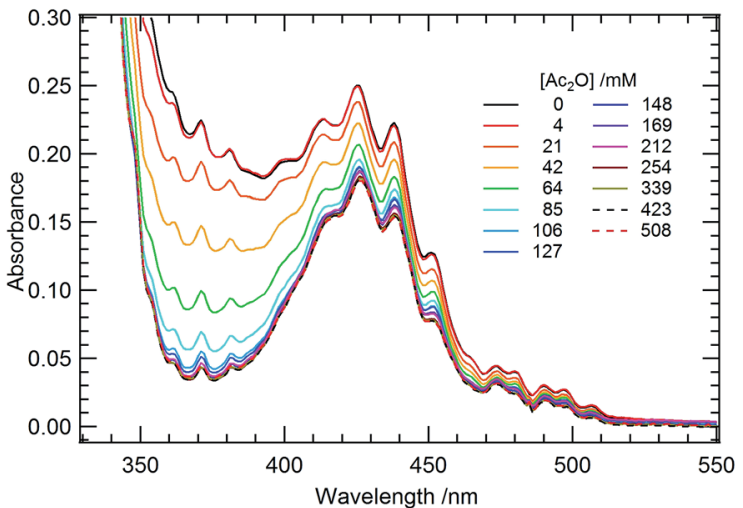

Fig. 4 UV-vis absorption spectra of a $\mathrm{CH}_{2} \mathrm{Cl}_{2}$ solution of $4\left(\mathrm{ClO}_{4}\right)_{2}(10$ $\mathrm{mM})$ at $22{ }^{\circ} \mathrm{C}$. $\left[\mathrm{Ac}_{2} \mathrm{O}\right]$ varied from 0 to $0.508 \mathrm{M}$.

2 components are involved in this spectral series. This result corroborates the occurrence of eqn (3) in the current system. In addition, the Job plot shown in Fig. S11 (ESI $\dagger$ ) also suggests a $1: 1$ interaction between 4 and $\mathrm{Ac}_{2} \mathrm{O}$ in eqn (3).

Although additional coordination to the fifth equatorial site of 4 is possible in a cooled solution (below $-40{ }^{\circ} \mathrm{C}$ ) as we have demonstrated the occurrence of $\left[\mathrm{UO}_{2}\left(\mathrm{OPPh}_{3}\right)_{5}\right]^{2+}(5)$ in the former ${ }^{40}$ there is not enough room for another ligand in the equatorial plane of 4 at $22{ }^{\circ} \mathrm{C}$ because of the thermal motion of the coordinated $\mathrm{OPPh}_{3}$ molecules.

$$
\left[\mathrm{UO}_{2}\left(\mathrm{OPPh}_{3}\right)_{4}\right]^{2+}(\mathbf{4})+\mathrm{OPPh}_{3}=\left[\mathrm{UO}_{2}\left(\mathrm{OPPh}_{3}\right)_{5}\right]^{2+}(\mathbf{5})
$$

Therefore, the exclusion of $\mathrm{OPPh}_{3}$ from the first coordination sphere of $\mathrm{UO}_{2}{ }^{2+}$ should be convincing. For the equilibrium analysis of the data in Fig. 4, it is necessary to know the number of released $\mathrm{OPPh}_{3}, n$, in eqn (3). Fig. 5 displays the ${ }^{31} \mathrm{P}\left\{{ }^{1} \mathrm{H}\right\}$ NMR spectrum of the $\mathrm{CD}_{2} \mathrm{Cl}_{2}$ solution containing $4(14.7 \mathrm{mM})$ and $\mathrm{Ac}_{2} \mathrm{O}(0.40 \mathrm{M})$ at $-70{ }^{\circ} \mathrm{C}$. The sample had to be cooled to suppress the frequency of the chemical exchange of the ligands bound to $\mathrm{UO}_{2}{ }^{2+}$. In accordance with our former findings, ${ }^{40}$ the ${ }^{31} \mathrm{P}$ signals at $53.1 \mathrm{ppm}$ and $41.4 \mathrm{ppm}$ were attributed to 4 and $\mathbf{5}$, respectively. The new signals at 47.6 and $46.6 \mathrm{ppm}$ appear upon the addition of $\mathrm{Ac}_{2} \mathrm{O}$. Upon increasing $\left[\mathrm{Ac}_{2} \mathrm{O}\right]$, the peak integrals of these signals increase, while the ratio between them remains constant at $2: 1$. Therefore, these signals should arise from the $\mathrm{OPPh}_{3}$ ligands in the different environments of a single uranyl complex other than 4 and 5 . The most plausible species occurring in this test solution is $\left[\mathrm{UO}_{2}\left(\mathrm{Ac}_{2} \mathrm{O}\right)\left(\mathrm{OPPh}_{3}\right)_{3}\right]^{2+}(\mathbf{6})$ as

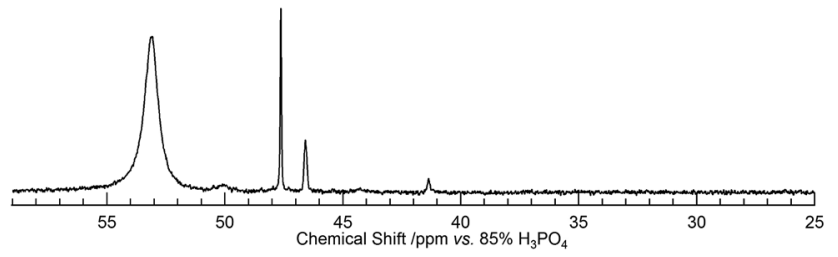

Fig. $5{ }^{31} \mathrm{P}\left\{{ }^{1} \mathrm{H}\right\} \mathrm{NMR}$ spectrum of $\mathrm{CD}_{2} \mathrm{Cl}_{2}$ solution dissolving 4 (14.7 $\mathrm{mM})$ and $\mathrm{Ac}_{2} \mathrm{O}(0.40 \mathrm{M})$ at $-70^{\circ} \mathrm{C}$.

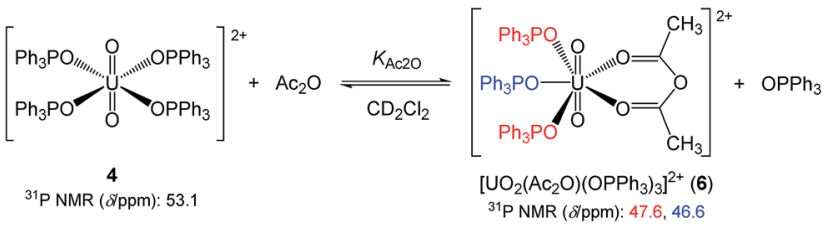

Scheme 1 The ligand substitution equilibrium between 4 and $\left[\mathrm{UO}_{2}(-\right.$ $\left.\left.\mathrm{Ac}_{2} \mathrm{O}\right)(\mathrm{OPPh})_{3}\right]^{2+}(6)$ in $\mathrm{CD}_{2} \mathrm{Cl}_{2}$ at $-70{ }^{\circ} \mathrm{C}$.

shown in Scheme 1, where two of the $\mathrm{OPPh}_{3}$ are chemically equivalent (red) and there is also another $\mathrm{OPPh}_{3}$ in a different environment (blue). The coordination mode of $\mathrm{Ac}_{2} \mathrm{O}$ may be bidentate in a similar manner to a $\beta$-diketonato ligand.

Note that no signals were observed at $29 \mathrm{ppm}$, where the ${ }^{31} \mathrm{P}$ signal of free $\mathrm{OPPh}_{3}$ appeared. This implies that the concentration of free $\mathrm{OPPh}_{3}$ was negligible. It is necessary to consider that $\mathrm{OPPh}_{3}$ in the product part of Scheme 1 is also involved in eqn (4). In accordance with our previous report, ${ }^{40}$ the logarithmic equilibrium constant of eqn (4) $\left(\log K_{45}\right)$ at $-70{ }^{\circ} \mathrm{C}$ is 3.33 , which reveals that $\left[\mathrm{OPPh}_{3}\right]_{\text {free }}$ is as small as $7 \times 10^{-6} \mathrm{M}$ under the current conditions. This is the reason why the free $\mathrm{OPPh}_{3}$ was undetectable in Fig. 5 .

The reaction in Scheme 1 was taken into account to analyze the UV-vis absorption spectral series shown in Fig. 4. Note that this treatment assumes that the equilibrium between $\mathbf{4}$ and $\mathbf{6}$ is also present in the current system at $22{ }^{\circ} \mathrm{C}$. It was also necessary to consider the following complexation to form 4.

$$
\mathrm{UO}_{2}{ }^{2+}+4 \mathrm{OPPh}_{3}=\left[\mathrm{UO}_{2}\left(\mathrm{OPPh}_{3}\right)_{4}\right]^{2+}(\mathbf{4})
$$

A sufficiently large gross stability constant of $4\left(\beta_{4}=[4] /\right.$ $\left[\mathrm{UO}_{2}{ }^{2+}\right]\left[\mathrm{OPPh}_{3}\right]_{\text {free }}{ }^{4}$, e.g., $\log \beta_{4}=20$ ) was assumed to simulate the predominant formation of $\mathbf{4}$ and practically negligible concentrations of free $\mathrm{UO}_{2}{ }^{2+}$. Formation of 5 can be ruled out at $22^{\circ} \mathrm{C}$ because $\log K_{45}$ is as low as -1.31 . Analysis using HypSpec software ${ }^{44}$ resulted in the logarithmic equilibrium constant of Scheme $1\left(\log K_{\mathrm{Ac}_{2} \mathrm{O}}\right)$ equal to $-0.513 \pm 0.013$ at $22{ }^{\circ} \mathrm{C}$. The characteristic LMCT bands arising from the $\mathrm{UO}_{2}{ }^{2+}$ moiety were assigned to both 4 and 6 as shown in Fig. S12 (ESI†), implying that the equilibrium analysis was successfully completed. It was also confirmed that the value of $K_{\mathrm{Ac}_{2} \mathrm{O}}$ was independent of the assumption of $\beta_{4}$ unless the occurrence of free $\mathrm{UO}_{2}{ }^{2+}$ was significant in the simulation (where $\log \beta_{4}<12$ ).

Assuming that complex 6 is an actual catalyst in the acetylation of $\mathrm{Ph}\left(\mathrm{CH}_{2}\right)_{2} \mathrm{OH}$, eqn (2) can be modified using $K_{\mathrm{Ac}_{2} \mathrm{O}}=$ [6] $\left[\mathrm{OPPh}_{3}\right]_{\text {rree }} /[4]\left[\mathrm{Ac}_{2} \mathrm{O}\right]$ as follows:

$$
v_{\text {ini }}=\left(k / K_{\mathrm{Ac}_{2} \mathrm{O}}\right)\left[\mathrm{Ac}_{2} \mathrm{O}\right][6]
$$

The rate constant $k / K_{\mathrm{Ac}_{2} \mathrm{O}}$ is equal to $1.31 \times 10^{-3} \mathrm{M}^{-1} \mathrm{~s}^{-1}$ at $22^{\circ} \mathrm{C}$. This rate equation indicates that the rate-determining step was the interaction between 6 and $\mathrm{Ac}_{2} \mathrm{O}$. Thus, $\left[\mathrm{UO}_{2}\left(\mathrm{Ac}_{2} \mathrm{O}\right)_{2}\right.$ $\left.\left(\mathrm{OPPh}_{3}\right)_{3}\right]^{2+}(7)$ will be formed as an intermediate to activate additional $\mathrm{Ac}_{2} \mathrm{O}$, followed by nucleophilic attack of $\mathrm{Ph}\left(\mathrm{CH}_{2}\right)_{2} \mathrm{OH}$ to the electrophilic carbon of the carbonyl moiety in the activated $\mathrm{Ac}_{2} \mathrm{O}$. Taking into account the following points, (i) the stoichiometry of 7, (ii) the absence of leaving $\mathrm{OPPh}_{3}$ supported by eqn 


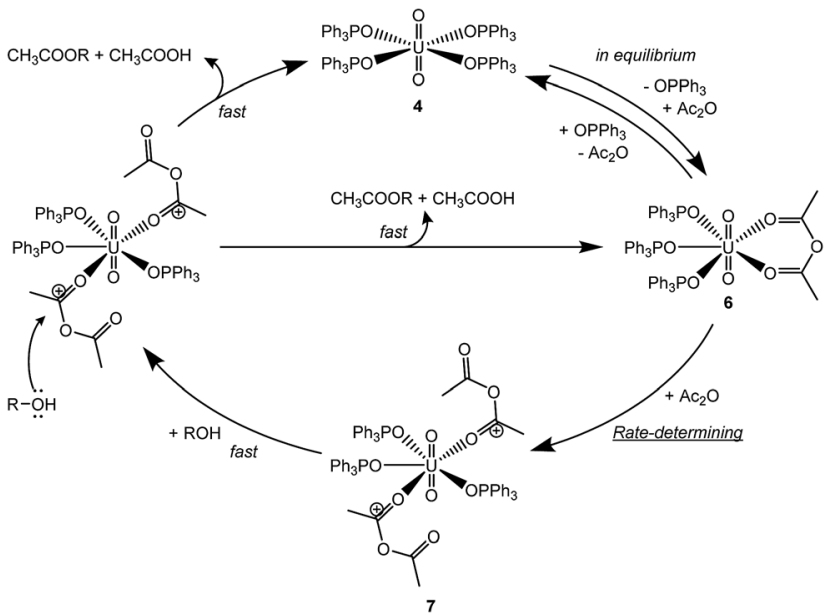

Scheme 2 The proposed cycle for the nucleophilic acyl substitution reaction of $\mathrm{Ac}_{2} \mathrm{O}$ catalyzed by $4\left(\mathrm{R}=\mathrm{Ph}\left(\mathrm{CH}_{2}\right)_{2}-\right)$. The charges on the uranyl complexes are omitted for clarity.

(6) and (iii) the potential bidentate coordination manner of $\mathrm{Ac}_{2} \mathrm{O}$, $\mathrm{UO}_{2}{ }^{2+}$ has to offer 7 coordination sites in its equatorial plane, being too crowded. Therefore, one or both of the coordinated $\mathrm{Ac}_{2} \mathrm{O}$ molecules should be monodentate. In the latter case, the coordination number in the equatorial plane is 5 , which is most commonly found in uranyl complexes. Although 6-fold uranyl complexes are also often observed, such a structure is allowed only by the chelating ligands bearing narrow bite angles such as $\mathrm{CO}_{3}{ }^{2-}$ and $\mathrm{NO}_{3}{ }^{-} .^{-45,46}$ In summary, the proposed catalytic cycle of the nucleophilic acyl substitution is shown in Scheme 2. This catalysis mechanism is plausible, but still somewhat hypothetical. Our trials to crystallize 6 and uranyl complexes related to intermediate $\mathbf{7}$ have not been successful to date.

Lewis-acid catalysis is widely employed in various organic syntheses. A typical example is the series of triflate salts of several d-block metals and trivalent rare earths used in aldol reactions, where the Lewis-acid catalysts are much easier to handle than those traditionally employed, such as $\mathrm{AlCl}_{3}$ and $\mathrm{BF}_{3} \cdot \mathrm{Et}_{2} \mathrm{O}$, because of their resistance towards hydrolysis. ${ }^{47}$ The uranyl species also does not show a strong tendency towards hydrolysis and therefore, can be present stably in aqueous or aqueous/organic biphasic reaction systems. Furthermore, the dioxo structure of uranyl may result in the equatorial coordination shown in this study, which is much distinguishable from the known spherical metal ions as water-compatible Lewis-acid catalysts. We intend to expand the coordination chemistry of uranyl to explore its catalytic functions.

\section{Conclusions}

In this study, we performed screening of several uranyl complexes as Lewis-acid catalysts used in the nucleophilic acyl substitution reaction. As a result, all the uranyl species tested were found to more or less promote this reaction to afford an ester and carboxylic acid. The most active uranyl complex in hand was $\left[\mathrm{UO}_{2}\left(\mathrm{OPPh}_{3}\right)_{4}\right]^{2+}(\mathbf{4})$, which gives ethyl acetate in $97 \%$ yield within $2 \mathrm{~h}$ at $22{ }^{\circ} \mathrm{C}$ in $\mathrm{CD}_{2} \mathrm{Cl}_{2}$. Several nucleophiles were used in the acetylation and pivalation reactions using the corresponding acid anhydrides in the presence of $\mathbf{4}$. In all the entries reported herein, the progress of these reactions was successfully enhanced by $\mathbf{4}$. Even when using ternary alcohols such as tert-BuOH and trityl alcohol, $\mathbf{4}$ still shows its activity, although progress of the reaction in both systems is somewhat slow. According to the kinetic and mechanistic studies, $\mathbf{4}$ is in an equilibrium with $\left[\mathrm{UO}_{2}\left(\mathrm{Ac}_{2} \mathrm{O}\right)\left(\mathrm{OPPh}_{3}\right)_{3}\right]^{2+}(\mathbf{6})$. Therefore, the former is a pre-catalyst and the latter is an actual catalyst in the current nucleophilic acyl substitution reaction.

\section{Experimental}

\section{Materials}

The uranyl complexes $\mathrm{UO}_{2}$ (salophen)EtOH $(\mathbf{1}){ }^{48} \mathrm{UO}_{2}(\mathrm{dbm})_{2^{-}}$ EtOH (2), ${ }^{49}\left[\mathrm{UO}_{2}(\mathrm{DMF})_{5}\right]\left(\mathrm{ClO}_{4}\right)_{2}(3),{ }^{50}$ and $\left[\mathrm{UO}_{2}\left(\mathrm{OPPh}_{3}\right)_{4}\right]\left(\mathrm{ClO}_{4}\right)_{2}$ $(4)^{40}$ (Fig. 1) were prepared by the methods described elsewhere. All the chemicals used in this study were of reagent grade and used as received.

\section{Kinetic and mechanistic studies using NMR spectroscopy}

${ }^{1} \mathrm{H}$ and ${ }^{31} \mathrm{P}\left\{{ }^{1} \mathrm{H}\right\}$ NMR spectra of the sample solutions were recorded on a JEOL ECX-400 NMR spectrometer $\left({ }^{1} \mathrm{H}: 399.78\right.$ $\mathrm{MHz},{ }^{31} \mathrm{P}: 161.83 \mathrm{MHz}$ ). Tetramethylsilane (TMS) and $85 \%$ $\mathrm{H}_{3} \mathrm{PO}_{4}$ were employed as reference materials for the ${ }^{1} \mathrm{H}$ and ${ }^{31} \mathrm{P}$ chemical shifts, respectively. A typical procedure used to study the reaction kinetics of the catalytic acyl substitution reaction is described below. The uranyl catalyst was loaded in an NMR sample tube (5 mm O.D.) together with $\mathrm{CD}_{2} \mathrm{Cl}_{2}$ and acid anhydride. After optimization of the NMR shim, a nucleophile was injected to the NMR tube. The sample solution was vigorously shaken, followed by starting the kinetic experiment. The ${ }^{1} \mathrm{H}$ NMR spectrum was recorded every 5-30 min. The concentrations of the reactants and products were estimated from the peak integrals of the species occurring in the reaction mixture.

\section{UV-vis titration experiments}

$\mathrm{A} \mathrm{CH}_{2} \mathrm{Cl}_{2}$ solution containing complex $4(10 \mathrm{mM})$ was prepared. This solution was titrated with neat $\mathrm{Ac}_{2} \mathrm{O}$. At each titration step, the UV-vis absorption spectrum of the sample solution was recorded on a Agilent 8453 photodiode array spectrophotometer. The obtained spectral series was analyzed using HypSpec software. ${ }^{44}$

\section{Acknowledgements}

We thank Prof. Emeritus Yasuhisa Ikeda and Prof. Emeritus Hirotake Moriyama for their stimulated discussions. This study was partially supported through the Assistant Staffing Program by the Gender Equality Center, Tokyo Institute of Technology.

\section{Notes and references}

1 M. Benedict, T. H. Pigford and H. W. Levi, Nuclear Chemical Engineering, McGraw-Hill, United States, 2nd edn, 1981. 
2 A. R. Fox, S. C. Bart, K. Meyer and C. C. Cummins, Nature, 2008, 455, 341-349.

3 E. Barnea and M. Eisen, Coord. Chem. Rev., 2006, 250, 855899.

4 E. Barnea, T. Andrea, M. Kapon and M. S. Eisen, J. Am. Chem. Soc., 2004, 126, 5066-5067.

5 E. Barnea, T. Andrea, M. Kapon, J. C. Berthet, M. Ephritikhine and M. S. Eisen, J. Am. Chem. Soc., 2004, 126, 10860-10861.

6 E. Barnea, D. Moradove, J.-C. Berthet, M. Ephritikhine and M. S. Eisen, Organometallics, 2006, 25, 320-322.

7 W. Ren, N. Zhao, L. Chen and G. Zi, Inorg. Chem. Commun., 2013, 30, 26-28.

$8 \mathrm{H}$. S. La Pierre and K. Meyer, in Progress in Inorganic Chemistry, ed. K. D. Karlin, John Wiley \& Sons, Hoboken, New Jersey, 2014, vol. 58, pp. 303-415.

9 S. Fortier and T. W. Hayton, Coord. Chem. Rev., 2010, 254, 197-214.

10 P. L. Arnold, A. F. Pecharman, E. Hollis, A. Yahia, L. Maron, S. Parsons and J. B. Love, Nat. Chem., 2010, 2, 1056-1061.

11 P. L. Arnold, E. Hollis, F. J. White, N. Magnani, R. Caciuffo and J. B. Love, Angew. Chem., Int. Ed. Engl., 2011, 50, 887-890.

12 J. B. Love, Chem. Commun., 2009, 3154-3165, DOI: 10.1039/ b904189c.

13 P. L. Arnold, A. J. Blake, C. Wilson and J. B. Love, Inorg. Chem., 2004, 43, 8206-8208.

14 P. L. Arnold, D. Patel, C. Wilson and J. B. Love, Nature, 2008, 451, 315-317.

15 R. G. Pearson, J. Am. Chem. Soc., 1963, 85, 3533-3539.

16 J. Maynadie, J. C. Berthet, P. Thuery and M. Ephritikhine, Chem. Commun., 2007, 486-488, DOI: 10.1039/b617700j.

17 T. W. Hayton, Chem. Commun., 2013, 49, 2956-2973.

18 P. L. Arnold and I. J. Casely, Chem. Rev., 2009, 109, 35993611.

19 J. C. Tourneux, J. C. Berthet, T. Cantat, P. Thuery, N. Mezailles and M. Ephritikhine, J. Am. Chem. Soc., 2011, 133, 6162-6165.

20 V. van Axel Castelli, R. Cacciapaglia, G. Chiosis, F. C. J. M. van Veggel, L. Mandolini and D. N. Reinhoudt, Inorg. Chim. Acta, 1996, 246, 181-193.

21 V. van Axel Castelli, A. D. Cort, L. Mandolini and D. N. Reinhoudt, J. Am. Chem. Soc., 1998, 120, 12688-12689.

22 V. van Axel Castelli, F. Bernardi, A. Dalla Cort, L. Mandolini, I. Rossi and L. Schiaffino, J. Org. Chem., 1999, 64, 8122-8126.

23 V. van Axel Castelli, A. Dalla Cort, L. Mandolini, D. N. Reinhoudt and L. Schiaffino, Chem.-Eur. J., 2000, 6, 1193-1198.

24 V. van Axel Castelli, A. Dalla Cort, L. Mandolini, D. N. Reinhoudt and L. Schiaffino, Eur. J. Org. Chem., 2003, 2003, 627-633.
25 V. van Axel Castelli, A. Dalla Cort, L. Mandolini, V. Pinto and L. Schiaffino, J. Org. Chem., 2007, 72, 5383-5386.

26 A. Dalla Cort, L. Mandolini and L. Schiaffino, J. Org. Chem., 2008, 73, 9439-9442.

27 A. Dalla Cort, L. Mandolini and L. Schiaffino, Chem. Commun., 2005, 3867-3869, DOI: 10.1039/b504713g.

28 R. J. Baker and A. Walshe, Chem. Commun., 2012, 48, 985987.

29 A. Walshe, J. Fang, L. Maron and R. J. Baker, Inorg. Chem., 2013, 52, 9077-9086.

30 J. Fang, A. Walshe, L. Maron and R. J. Baker, Inorg. Chem., 2012, 51, 9132-9140.

31 M. J. Sarsfield and M. Helliwell, J. Am. Chem. Soc., 2004, 126, 1036-1037.

32 T. W. Hayton and G. Wu, Inorg. Chem., 2009, 48, 3065-3072. 33 C.-T. Chen, J.-H. Kuo, C.-H. Li, N. B. Barhate, S.-W. Hon, T.-W. Li, S.-D. Chao, C.-C. Liu, Y.-C. Li, I. H. Chang, J.-S. Lin, C.-J. Liu and Y. C. Chou, Org. Lett., 2001, 3, 37293732.

34 C. T. Chen, J. H. Kuo, V. D. Pawar, Y. S. Munot, S. S. Weng, C. H. Ku and C. Y. Liu, J. Org. Chem., 2005, 70, 1188-1197.

35 K. Takao and Y. Ikeda, Inorg. Chem., 2007, 46, 1550-1562.

36 Y. Ikeda, H. Tomiyasu and H. Fukutomi, Inorg. Chem., 1984, 23, 1356-1360.

37 Y. Ikeda, H. Tomiyasu and H. Fukutomi, Inorg. Chem., 1984, 23, 3197-3202.

38 J. C. Berthet, M. Nierlich and M. Ephritikhine, Angew. Chem., Int. Ed., 2003, 42, 1952-1954.

39 G. H. John, I. May, M. J. Sarsfield, H. M. Steele, D. Collison, M. Helliwell and J. D. McKinney, Dalton Trans., 2004, 734740, DOI: $10.1039 / \mathrm{b} 313045$ b.

40 K. Takao, T. Takahashi and Y. Ikeda, Inorg. Chem., 2009, 48, 1744-1752.

41 R. D. Shannon, Acta Crystallogr., Sect. A: Cryst. Phys., Diffr., Theor. Gen. Crystallogr., 1976, 32, 751-767.

42 A. Rossberg, T. Reich and G. Bernhard, Anal. Bioanal. Chem., 2003, 376, 631-638.

43 K. Takao, S. Takao, Y. Ikeda, G. Bernhard and C. Hennig, Dalton Trans., 2013, 42, 13101-13111.

44 A. Sabatini, A. Vacca and P. Gans, Coord. Chem. Rev., 1992, 120, 389-405.

45 D. L. Clark, D. E. Hobart and M. P. Neu, Chem. Rev., 1995, 95, 25-48.

46 K. Takao, K. Noda, Y. Morita, K. Nishimura and Y. Ikeda, Cryst. Growth Des., 2008, 8, 2364-2376.

47 S. Kobayashi and K. Manabe, Acc. Chem. Res., 2002, 35, 209217.

48 K. Takao and Y. Ikeda, Inorg. Chem., 2007, 46, 1550-1562.

49 K. Mizuoka and Y. Ikeda, Radiochim. Acta, 2004, 92, 631-635.

50 K. Takao, S. Takao, Y. Ikeda, G. Bernhard and C. Hennig, Dalton Trans., 2013, 42, 13101-13111. 